\title{
The Censorship of Essays Written by Maria Aurèlia Capmany (1968-1978)
}

\author{
Francesc Foguet i Boreu* (Universitat Autònoma de Barcelona) \\ Francesc.Foguet@uab.cat http://orcid.org/0000-0003-4083-5486
}

\begin{abstract}
General Franco's censorship apparatus was quick to pounce on the intellectual dissent in the essays written by Maria Aurèlia Capmany from 1968 to 1978. Based on censorship records, this article analyses the ideological way that those in charge of issuing the reports read her essays. The essays that suffered the most in the hands of the censors were La joventut és una nova classe? (1969), Pedra de toc (1970), El feminismo ibérico (1970) and El feminisme a Catalunya (1973).
\end{abstract}

Keywords: Maria Aurèlia Capmany, essays, history, sociology, feminism, censorship, Francoist regime

\section{Introduction}

Maria Aurèlia Capmany was one of the most prominent Catalan authors when literary production recovered following the end of the Spanish Civil War. However, like all books published legally during Franco's dictatorship, Capmany's works of literature had to pass through the filters of official censorship, which were particularly strict with essays, especially those penned in Catalan. The censorship records are held in the General Archive of the Administration (AGA) in Alcalá de Henares, near Madrid, and the reports for Capmany's first volumes of essays, published between 1968 and 1978, illustrate how those in charge of censorship read them in a highly ideological way, with a keen eye for even the slightest hint of dissent towards the regime's ideology. The readers who issued censorship reports for her books reacted strongly to - and were often confused by - her hybrid essays that shifted freely between the present and the past, from one reference or discipline (literature, philosophy, sociology or politics) to another, and amongst closely related genres such as memoir and journalism.

\section{Sociological essays and memoirs}

Capmany "voluntarily" sent La joventut és una nova classe? [Is youth a new class?] to the censorship office in the fall of 1968, and the essay did not come out unscathed. One reader's report suggested deleting pages 127134 from the original manuscript that had been submitted, believing the author had gone too far in "granting specific, unlimited rights to the said youth in the area of sexuality." Only after Ramon Bastardes Porcel,

\footnotetext{
* Francesc Foguet i Boreu is Associate Professor of Catalan Literature at the Department of Catalan Philology, Faculty of Arts and Humanities of the Universitat Autònoma de Barcelona. He specialises in the study of modern and contemporary theatre in Catalonia. One of his most recent publications is, with Sharon Feldman 'The Limits of Silence. The Censorship of Catalan Theatre during Francoism' (2016). He is a member of the Centre for Studies on the Franco and Democratic Eras (CEFID-UAB) and he is coordinator of the official inter-university master's degree in Theatre Studies of de UAB.
} 
representing the publishing house Edicions 62 , had delivered a new text that replaced the questionable section, did the censors allow the book to be published, two months after the application had been submitted. The new version - published with only a few minor changes - took ironic refuge in philosophical, sociological and moral literature and disquisitions on the era's youth and their sexual behaviours and attitudes, avoiding a more overt, realistic, down-to-earth viewpoint that openly denounced the repressiveness of Catholic morality.

\begin{tabular}{|c|c|}
\hline Deleted section & New/edited text \\
\hline $\begin{array}{l}\text { "[James] Joyce could deftly reproduce the } \\
\text { formula used in Catholic confessions: } \\
\text { - How long is it since your last confession, my } \\
\text { child? } \\
\text { - A long time, father. } \\
\text { - A month, my child? } \\
\text { - Longer, father. } \\
\text { - Three months, my child? } \\
\text { - Longer, father. } \\
\text { - Six months? } \\
\text { - Eight months, father. } \\
\text { He had begun. The priest asked: } \\
\text { - And what do you remember since that time? } \\
\text { He began to confess his sins: masses missed, } \\
\text { prayers not said, lies. } \\
\text { - Anything else, child? } \\
\text { Sins of anger, envy of others, gluttony, vanity, } \\
\text { disobedience. } \\
\text { - Anything else, my child? } \\
\text { There was no help. He murmured: } \\
\text { - I ... committed sins of impurity, father. } \\
\text { The priest did not turn his head. } \\
\text { - With yourself, my child? } \\
\text { - And ... with others. } \\
\text { - With women, my child? } \\
\text { - Yes, father. } \\
\text { - Were they married women, my child? } \\
\text { He did not know. His sins trickled from his } \\
\text { lips, one by one, trickled in shameful drops from } \\
\text { his soul, festering and oozing like a sore, a } \\
\text { squalid stream of vice. The last sins oozed forth, } \\
\text { sluggish, filthy. There was no more to tell. [He } \\
\text { bowed his head, overcome. The priest was } \\
\text { silent.] Then he asked: } \\
\text { - How old are you, my child? } \\
\text { - Sixteen, father.' } \\
\text { Sex is a subject one talks about quietly, } \\
\text { separately from man's visible life. What boys } \\
\text { learn at home and in school is that behaviour is } \\
\text { one thing and permissible vocabulary quite } \\
\text { another. } \\
\text { Not long ago, at a fairly modern school in our } \\
\text { city, I found a book for children. I guess it was for } \\
\text { children who were just starting to read, given the } \\
\text { size of the letters. The first page had a description } \\
\text { of the human body. The boy in the illustration } \\
\text { was wearing briefs. You could mentally work } \\
\text { your way down, naming the body parts using } \\
\text { words you had to memorise: the forehead, the }\end{array}$ & 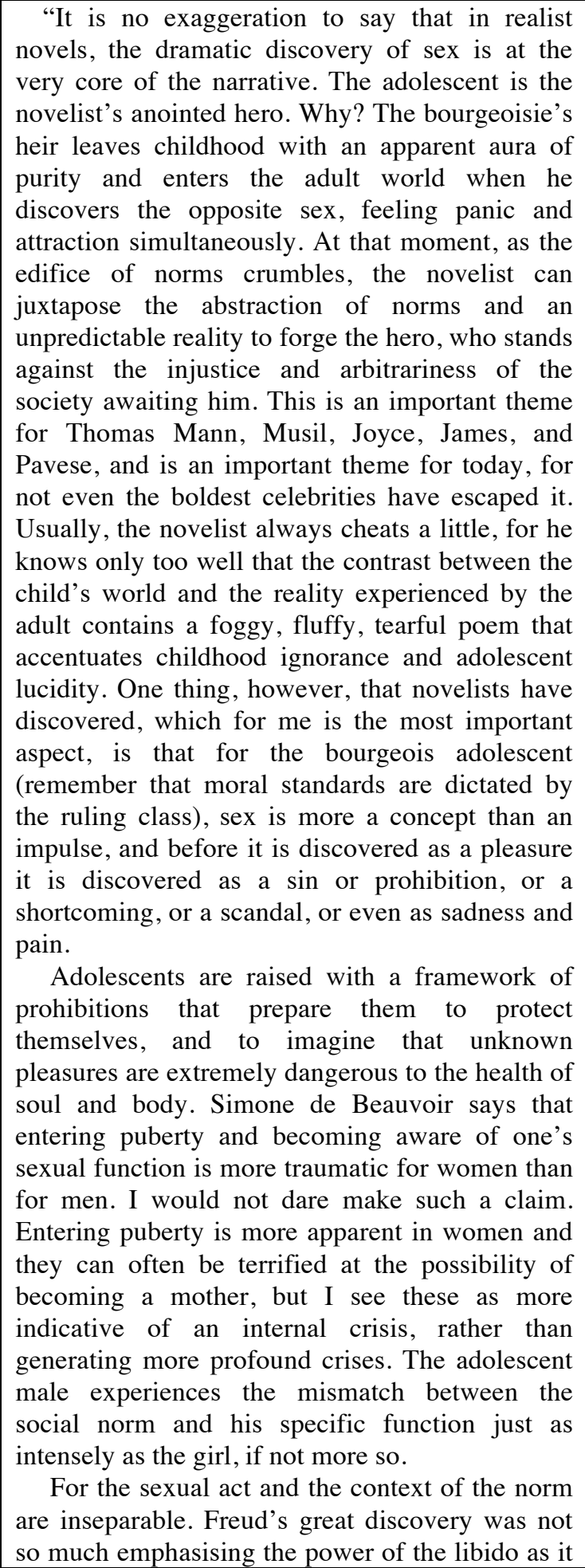 \\
\hline
\end{tabular}

${ }^{1}$ The section in square brackets is part of Joyce's original text, but was omitted in Capmany's translation into Catalan. 
eyes, the lips, etc. When you reached the briefs, your young mind would have to put its scientific curiosity on hold until you got down to the thighs, when that curiosity would return. I found the illustration symptomatic of a false liberating attitude: if we compare the picture of the boy in his underpants with the pictures that schoolchildren used to see, the person behind this primer could claim that we have moved forward along the path of nakedness, i.e., of knowledge itself. However, it so happens that this sanctioned nudity makes the disapproval of sexual curiosity even more patent, since covering up this part of the body with underwear means that in the best case scenario, i.e., if the teacher offers sexual guidance, it takes place separately from the rest of the child's education, as if that part of the body, whether reviled or revered, were totally unconnected to asexual harmony, a legitimate topic of conversation, with useful vocabulary.

A young child quickly learns to appreciate the importance of sex, long before the emotional tension of that appreciation can be expressed consciously. By adolescence, when people either rebel against prevailing morality or accept it submissively, their autonomous desires and tendencies are already fully in place.

In this country, where Catholic morals are the norm, even in the most secular schools, the outline for sexual behaviour is not all that different from the one offered by Joyce through his confession. The vocabulary has certainly changed: adjectives do not evoke poison or curses. But the ideal of purity is put forward as a sports brand, as something one must acquire with gay abandon. The smiling teacher tells the child: "Here you are. Here's the key to how your sexuality works. Use it well; don't waste it." If the information arrives on time-before the young person gathers information through his own field research - the real world is where he must begin to live, a real world dominated by the model seen in that childhood primer.

So much literature expresses horror at the sexual behaviour of today's youth. The drama of a mother who finds birth control pills in her daughter's purse has replaced the old drama of the mother saying, "My daughter, you've lost your virtue." The tension of the old melodrama has gone, but there is still the idea of standards versus inappropriate behaviour, albeit expressed in different terms. In fact, that idea is even stronger, because there is never quite full harmony between the pressure of traditional morality and the content of a liberating education.

The moral that the priest preaches at the end of a confession is clear: Except for sex within marriage for purposes of procreation, all sexual acts are transgressions, whether the impure act is committed with a person of the opposite sex, the was making the social structure of sexual behaviour evident.

Whatever morality is accepted-Catholic or otherwise-the adolescent becomes aware of sex with a whole series of dogmatic preconceptions. The more advanced, liberal schools refer to sex education and teach it very competently. It is always surprising when a good educator believes he has solved the problem, and that sex education can take place separately from a person's overall education. This means that it is so easy to find amongst today's youth a defiant behaviour, sometimes involving outright promiscuity, in people who at the same time have a totally conformist mental structure. Such an attitude is more about romanticising defiance than about reconsidering values.

The social dimension of sex is made even more evident by the exaltation of sex that we see in all kinds of advertisements, from luxury automobiles to such things as soup pasta and, of course, attire, which is rather more essential for amorous activities. A new, falsely liberating side of the sexual taboo has emerged. Sex in advertising slogans and consumer literature is the remedy for all evils, the way out of all conflicts, the keystone that must support the building that is our spiritual balance. Behind this mass advertising, directed mainly at youth, is a false formula for liberation from the old form of morality that talks about balance and pleasure without frustrations. However, one always forgets that the repression that changes one's sex drive is connected to morality and socioeconomics, rather than biology.

The sex drive that pushes boys and girls to come together to reach their full potential is taken into account by the very structure of the society in which they live: prestige, safety and domination blend together with the very nature of the drive, making it impossible to separate them out. A sixteen-year-old boy and girl who are biologically fit to come together and find the happiness they desire are surrounded by as many hurdles to consummation as the lovers in a Byzantine novel. So much so that to reduce these difficulties, young people today tend to marry early. Consequently, the young couple find themselves obliged to follow social behavioural norms that they had been unwilling to adopt.

The purpose of society's repression of the sexual impulse is, without any shadow of a doubt, to have monogamous couples to achieve the perfect family unit. The entire social order is shaped to accept the monogamous couple. It is impossible for those who ignore these norms to achieve a stable position in this society. All sexual activity involves an initial repression, which is unaware that it produces a wide variety of tendencies of sexual appetite, ranging from 
same sex, or oneself. The simplistic nature of the prohibition can plunge the believer into a state of distress when he feels too weak to abstain from that forbidden act, yet the believer can get his life back in order through a system of compensations and continuity, by starting over on the right track.

The modern world, however, has discovered the importance of sex. The sexual act is not bad; quite the opposite. First, it is a source of pleasure. More importantly, it ensures balance. But this sought-after balance and this pleasure without frustration rarely happen because the repression that shapes our sex drive is not biological but socioeconomic. The sex drive that pushes a boy or girl to consummate the act is taken into account by the very structure of the society in which they live: prestige, safety and domination will blend together with the very nature of the drive, making it impossible to separate them out. A sixteen-year-old boy and girl who are biologically fit to come together and find happiness are surrounded by as many hurdles to consummation as the lovers in a Byzantine novel. If they belong to the middle bourgeoisie, everyone makes them wait a while, which only further complicates the uncertainty of that drive. If they doggedly stand against the prevailing morals and adopt a somewhat promiscuous lifestyle, the random break-ups of such unions will necessarily make the young person more combative and thus more likely to contradict standards than to see them as beneficial. The other solution - marrying at a very young age requires the couple to follow certain social behavioural norms that young people are not willing to adopt. The purpose of society's repression of sexual impulses is, without any shadow of a doubt, to have monogamous couples, which is optimal for reproduction. The entire social order is shaped to accept this monogamous couple. It is impossible for those who ignore these norms to achieve a stable position in this society. This initial repression can produce a variety of tendencies in the individual's sexual appetite, ranging from self-abuse and heterosexuality to homosexuality. When a young person discovers the possibility of pleasure, he also discovers that finding satisfaction means shrewdly battling against all the obstacles to pleasure. Sexual satisfaction therefore necessarily becomes associated with the idea of shrewdness, trickery and triumph.

Besides the obstacles to sex and its attendant pleasures, the young person is bombarded with propaganda, most of which shows him that if he is unable to achieve this wonderful ecstasy, he is a defeated person. He has been denied his fair share of pleasure in a world where others enjoy life. He therefore seeks this pleasure through a secondary need that is even more insistent than self-abuse and heterosexuality to homosexuality.

Besides the obstacles to sex and its attendant pleasures, the young person is bombarded with propaganda, most of which shows him that if he is unable to achieve this wonderful ecstasy, he is a defeated person, or rather a person incapable of triumphing. Slogans assure him that, if he does not hurry, he will be denied his fair share of pleasure in a world where others enjoy life. Without realizing, he therefore seeks this apparent success through a need that is more insistent than the primary need that is his sex drive.

In the tumultuous gatherings of young people, sexuality is not a drive that must be satisfied, but rather the way out that must be found, with the help of a beat and alcohol. Articles and books discussing youth very often lament the coldness of their relationships, appealing to the passionate warm lovemaking of yesteryear. In his book Probleme der jungen Generation, Fischer launches a long tirade against what he calls "cool sex," and then, in the name of "humanity," he discusses well-known "historical" couples:

"At the risk of sounding like an incurable conservative to younger readers, I cannot hide the fact that I consider the love affairs of Héloïse, young Werther, Helen in the magic mirror, and the Duchess of Sanseverina to be just as important as the invention of the steam engine or fission of the atomic nucleus."

Interestingly, Fischer's examples of exemplary love are all tragic, adulterous affairs that are of a heroic nature because people go against the laws of the society in which they live. In literature, love stories rarely occur in wedlock, the useful social unit. To find the reason for this, we must look beyond mere stories of people falling in love. Werther's drama is made by the unjust social structure, not only by his falling in love.

It is true that the new youth are trying to escape by blindly feeling their way out, because seeing the world through completely fresh eyes is beyond them. The only thing that reassures us is the growing, visible desire to tackle this situation and these difficulties head on."

(pp. 128-132) (Capmany, 1969: 144-149) 
the primary need that is his sex drive. Movies, advertisements and magazines constantly portray perfect couples enjoying the success of being with their soul mate, so the young person has to find his soul mate using whatever means he can, and if he does not find that soul mate, he is a failure. His search for completeness is so desperate and solitary that it is hardly surprising that he often resorts to inversion or the most unbridled forms of promiscuity.

In the tumultuous gatherings of young people, sexuality is not a drive that must be satisfied, but rather a way out that must be found. With the help of a beat and alcohol, the boy or girl seeks a release through orgasm. This occurs if the act is consummated, but most relations between young people involve a derivative form of sexuality that is satisfied by what Americans call "petting.,"

Articles and books discussing youth very often lament the coldness of their relationships, appealing to the passionate warm lovemaking of yesteryear. In his book Probleme der jungen Generation [The problems of the young generation], Fischer launches a long tirade against what he calls "cool sex," and then, in the name of "humanity," he discusses well-known "historical" couples:

"At the risk of sounding like an incurable conservative to younger readers, I cannot hide the fact that I consider the love affairs of Héloïse, young Werther, Helen in the magic mirror, and the Duchess of Sanseverina to be just as important as the invention of the steam engine or fission of the atomic nucleus."

Interestingly, Fischer's examples of ardent love are all tragic, adulterous affairs in which people go against the laws of the society in which they live. In literature, love stories rarely occur in wedlock, and perhaps the examples of the most famous lovers serve to show that the love lives of couples who came together according to norms are lukewarm at best. The new youth sometimes seem like they are trying to escape by blindly feeling their way out, but perhaps their struggle is to find a form of human behaviour that does not assume that following norms requires choosing between fulfilment of duty and happiness.

What is sure is that young people are increasingly living further from adults and the family home, thanks to the concentration of people in large universities. Perhaps in this shared environment they will find the pathway that the society in which we live, still based on Neolithic moral standards, has been unable to give them." (pp. 127-134)

Source: AGA, (03)050, c. 21/19242, e. 7927/68

${ }^{2}$ Capmany used the English term "petting" in her Catalan text. 
When, two years later, in the fall of 1970, Pedra de toc [Touchstone] was sent to the censors, the readers did not appreciate the book at all, immediately pointing out its "political overtones." One censor, Francisco Galí, wrote in his report: "The deplorable start to the book expresses the thoughts of a defeated person, of the loser of a war who settled in an environment to which the author is averse. She seems gradually to acclimatise, and the rest of the story paints a much less bitter picture, though the sarcasm continues." Despite these remarks, the final decision simply calls for the removal of several passages from the book, which the editor at Nova Terra, Joan Carrera, had no alternative but to accept in order for the book to be published. They were basically short segments (struck through in the left-hand column below) referring to the new social and political situation following the rise to power of the dictator Francisco Franco: the hardships of the vanquished, the post-war moral orthodoxy, the "long night" of Franco's dictatorship and the repression of Catalan nationalism.

\begin{tabular}{|c|c|}
\hline Text submitted to censorship & \\
\hline $\begin{array}{l}\text { "During that summer of ' } 39 \text {, we turned our backs } \\
\text { on a whole era, and beyond the war lay a remote } \\
\text { world that was completely unconnected to the life } \\
\text { we had been living. It was a summer of hard work: } \\
\text { we retook courses we'd already taken, not too } \\
\text { aware that the new school year was one big joke. } \\
\text { Not too aware, I say, becatse we were losing the } \\
\text { ability to be surprised. Then, some short news } \\
\text { items in the papers informed us that the Spanish } \\
\text { government now officially recognised certain } \\
\text { curricula that had been invalid in the summer of } \\
\text { ' } 39 \text {. We had to take our exams all over again, and } \\
\text { we had to relearn the lessons we had forgotten: } \\
\text { formulae for chemistry, laws for physics, axioms } \\
\text { for mathematics. We had to go through all of that } \\
\text { again to be readmitted at university. Call us } \\
\text { "numbed" if you will, but we accepted the vexing } \\
\text { examination of skills that we had already shown } \\
\text { that we had, because we still saw the value of } \\
\text { university." (p. 2) }\end{array}$ & $\begin{array}{l}\text { "During that summer of ' } 39 \text {, we turned our backs } \\
\text { on a whole era, and beyond the war lay a remote } \\
\text { world that was completely unconnected to the life } \\
\text { we had been living. It was a summer of hard work: } \\
\text { we retook courses we'd already taken. Then, some } \\
\text { short news items in the papers informed us that the } \\
\text { Spanish government now officially recognised } \\
\text { certain curricula that had been invalid in the } \\
\text { summer of " } 39 \text {. We had to take our exams all over } \\
\text { again, and we had to relearn the lessons we had } \\
\text { forgotten: formulae for chemistry, laws for } \\
\text { physics, axioms for mathematics. We had to go } \\
\text { through all of that again to be readmitted at } \\
\text { university. Call us "numbed" if you will, but we } \\
\text { accepted the examination of skills that we had } \\
\text { already shown that we had, because we still saw } \\
\text { the value of university." (Capmany, 1970a: 12) }\end{array}$ \\
\hline $\begin{array}{l}\text { S of the fear of bombs, the fear of } \\
\text { of the purging commissions, the } \\
\text { ight that lay ahead for us." (p. 3) }\end{array}$ & $\begin{array}{l}\text { id ourselves of the fear of bombs, the fear of } \\
\text {, the fear of the purging commissions." } \\
\text { any, 1970a: 13) }\end{array}$ \\
\hline $\begin{array}{l}\text { "That poetry book [Bartolomeu Rosselló-Pòrcel's } \\
\text { Imitació del foc (Imitation of fire)] was ours, } \\
\text { because it was our death. There are many ways to } \\
\text { die, and we had passed the national examination, } \\
\text { we had made it through the purging commission, } \\
\text { and we had made statements on oath. We had } \\
\text { inaugurated the long period of Averroism from } \\
\text { which we werld never escape. Siger of Brabant } \\
\text { had-solved the issue of orthodoxy and freedom } \\
\text { through his theory of double truth. We would } \\
\text { invent a new ethical Averroism." (p. 4) }\end{array}$ & $\begin{array}{l}\text { "That poetry book was ours, because it was our } \\
\text { death. There are many ways to die, and we had } \\
\text { passed the national examination, we had made it } \\
\text { through the purging commission, and we had made } \\
\text { statements on oath." (Capmany, 1970a: 13-14) }\end{array}$ \\
\hline $\begin{array}{l}\text { "Acknowledging oneself as thrown in here was, } \\
\text { subjectively speaking, satisfactory. The expression } \\
\text { "being tossed" involved a trace of emotion, a sense } \\
\text { of urgency-despite being aware that the original } \\
\text { word did not have the sense of scorn that exists in } \\
\text { the word "tossed"- that at the same time was } \\
\text { reassuring, since it rationalised the painful } \\
\text { stampede that was three years of war,experiencing } \\
\text { defeat; a defeat that made us disebedient and }\end{array}$ & $\begin{array}{l}\text { "Acknowledging oneself as thrown in here was, } \\
\text { subjectively speaking, satisfactory. The expression } \\
\text { "being tossed" carried a trace of emotion, a sense } \\
\text { of urgency - despite being aware that the original } \\
\text { word did not have the sense of scorn that exists in } \\
\text { the word "tossed"- that at the same time was } \\
\text { reassuring, since it rationalised the painful } \\
\text { stampede that was three years of war." (Capmany, } \\
\text { 1970a: 30) }\end{array}$ \\
\hline
\end{tabular}


therefore unnecessary." (p. 24)

"It is not at all difficult to draw parallels between the youth for whom the war ended in victorious Paris and our youth in vanquished Barcelona, though it is difficult to transcribe it in pictures, because we did not live a street life." (p. 26)

"A UFA newsreel showed cruel pictures of the defeat. It was not bloody cruelty, but was evidence of a new art form for us, and although we had just experienced a mereiless war, this was the art of destroying a person, turning that person into livestock, and pushing man to the ultimate level of degradation." (p. 36)

"My aunt used this phrase ['What a farce!'] to express her bewilderment, that is all. But as a result she went on file as being a red separatist. My Aunt Mercè was definitely not a red; who knows whether she was a separatist! Given the mountains of reports that existed, we must conclude that separatism was not a minority viewpoint." (p. 40) "Joaquim Molas's rationalism is admirably rigorous. His reasoning was as follows: For Catalonia to be a proper nation, it should be like so, like so and like so; only then can it produce a culture that is right and proper." (p. 166)

"It is not at all difficult to draw parallels between the youth for whom the war ended in victorious Paris and our youth in peaceful Barcelona, though it is difficult to transcribe it in pictures, because we did not live a street life." (Capmany, 1970a: 32)

"A UFA newsreel showed cruel pictures of the defeat. It was not bloody cruelty, but was evidence of a new art form for us, and although we had just experienced a war, this was the art of destroying a person, turning that person into livestock, and pushing man to the ultimate level of degradation." (Capmany, 1970a: 40)

"My aunt used this phrase to express her bewilderment, that is all. But as a result she went on file as being a red separatist. My Aunt Mercè was definitely not a red; who knows whether she was a separatist!" (Capmany, 1970a: 43-44)

"Joaquim Molas's rationalism is admirably
rigorous. His reasoning was as follows: For Catalonia to be as it should, it should be like so, like so and like so; only then can it produce a culture that is right and proper." (Capmany, 1970a: 154)

Source: AGA, (03)050, box 66/06087, file 9709/70.

By contrast, when an edited copy of Pedra de toc 2 [Touchstone 2] was deposited with the censors - as was mandatory - in December 1974, it fell on deaf ears, and was not returned. The report based on the published book, signed by a reader whose signature is illegible, was quite explicit:

In this rather sui generis memoir, the author recalls her own impressions and sentiments from 1939 to the present day. She alludes to national and international politics, but the main protagonist is Catalan culture: its forced silence, its subsequent attempt to find its voice, and the "triumphalism of the victors," etc., etc.

Without being overtly aggressive, the author reveals her well-known ideology through sophisticated reservations or sharp satire, or by reproducing the most triumphalist newspaper extracts from that period. The most striking examples are on pages 11, 37, 46, 63, 65, 98, 109, 148, 162 and on the inside flap.

I am afraid that there are not sufficient grounds to oppose the deposit, so I am inclined to advise administrative silence. ${ }^{3}$ [AGA (03)050, c. 73/04555, e. 13523/74]

The extracts marked in red by the reader alluded to the socio-political status imposed on the "vanquished" after 1939, the repression of the Catalan people by the dictatorship, the need to remember it, explain it and better understand it in order to live, and the hopes of change driven by the protest movements organised by the Catalan youth of the time.

History has been made by the victors, with the acquiescence of the indifferent. Those who win must be right; otherwise, reality would be turned on its head. Furthermore, Catalans who speak out loud, who "enter" Barcelona, are in no doubt about the huge importance that the fall of Catalonia has on the whole of Spain. They can exhibit a document published in [the journal] Destino, which had not yet reached

\footnotetext{
${ }^{3}$ Spanish: silencio administrativo. This concept in Spanish law refers to the failure of an administrative body to respond to an application or request.
} 
Barcelona and had not yet been imposed on Catalan homes through the force of weapons (according to Ridruejo). (Capmany, 1974a: 11)

These things were not a peaceful, tranquil experience; there was anguish, arguments, and some hope. (Capmany, 1974a: 37)

Slowly but surely, as one might have expected, literature altered by the fascist mind-set were introduced, and that rhetoric was not dependent on only one rhetoric, and it did not need to resort to attacks and insults, since we were heading fully into a period marked by welfare for a select group, which already had its apologists. (Capmany, 1974a: 46)

This was the death we were suffering, and we were close to dying definitively. (Capmany, 1974a: 63)

Nothing is fortuitous, everything was foreseeable, and the victors are always the good guys. You merely have to find out where the good guys are just before the battle ends. (Capmany, 1974a: 65)

I am not sure whether I should say that Sartre's novel influenced us or that it took place within the climate that we had ended up living in, that is, a climate of continual frustration, rage and resentment. (Capmany, 1974a: 98)

[...] the miserly good fortune of a servile, beaten people. (Capmany, 1974a: 109)

For a people is formed not by scroungers and opportunists, nor by "the scribe who sells his quill to victorious old hacks and stoops so low that, whether for gold or out of fear, he extols the sabre and triumph," as Espriu puts it in his Primera Història d'Esther [First Story of Esther]. (Capmany, 1974a: 148)

Those three days at the Capuchin friary, with all those joyful, self-denying, happy, beautiful young people was like a renaissance for me. To understand the change that had happened, I wrote La joventut és una nova classe? [Is youth a new class?] [...] and it was while I was writing it that the incredible, unforgettable events of 1968 in Paris took place. The words of the great political cartoonist Siné summarise this clear impression that I had. L'Action, the mouthpiece of the students:

"I swear I have seen CRS officers armed to the teeth back away when confronted with the bare hands of students. For that alone I believe it was worth coming into the world." (Capmany, 1974a: 162)

Those of us who have experienced the profound agony of this world since 1939 will all tell our story once, twice, three times... as often as possible in order to understand it and achieve the right to live. (inside flap)

Her collection of articles, by contrast, made it through the labyrinth of censorship corridors fairly easily. When Dia sí, dia no [Every other day] went through "voluntary censorship" in the winter of 1967, it passed through without any hiccups. The final authorisation was granted on September 6, 1968, once the procedures required for the prior deposit had been completed. The articles had already appeared in Presència, so they had already been published. They served a literary purpose and covered a range of topics that, in theory, were not considered "dangerous." Nevertheless, in his report, censor José Mampel could not resist mentioning one of the pieces included:

There is an article in favour of the unity of the Catalan language, ${ }^{4}$ but not in a controversial, pushy way, but rather with the intention of preserving its purity.

It is all perfectly admissible.

May be authorised. [AGA, (03)050, c. 21/18596, e. 9810/67]

Similarly, another miscellaneous work by Capmany, called Cada cosa en el seu temps [Everything in its time], completed the necessary deposit procedures in only five days, without any difficulty, in early June 1976. The

\footnotetext{
${ }^{4}$ That is, the fact that all varieties of Catalan, including those spoken in the Valencia region and the Balearic Islands, constitute a single language. Some groups had begun to promote the idea that Valencian was a language in its own right, rather than a variety of Catalan.
} 
report issued by censor number 17, probably Mateo Villalba, emphasised that the book had twelve chapters, one for each month of the year, and that it was comprised of "popular sayings, festivals, Catalan customs, legends and traditions, literary critique, etc.” The report's overall assessment was favourable:

A book containing a hodgepodge of miscellaneous items. Literary critique is the main type of content, and it is concerned more with style than with substance. I did not observe in the book any major obstacles to its publication. [AGA, (03)050, c. 73/05532, e. 6554/76]

\section{Feminist essays}

As it had already done with La joventut és una nova classe? and the two volumes of Pedra de toc, Franco's censorship apparatus also went through Capmany's 1960s and 1970s essays on feminism with a fine-tooth comb, with varying results. For instance, La dona a Catalunya [Woman in Catalonia], which was submitted to the censors on December 9, 1965, had no difficulties in obtaining authorisation for publication (though the final decision was not made until May 10, 1966, once copies had been formally deposited). José Mampel signed the only report in the essay's file, which reads as follows:

The work is ambitious, but also unfocused and lacking clarity. Contrary to what the title suggests, it actually discusses woman in general, and the Spanish woman more than the Catalan woman; it never compares the Catalan woman with the Spanish woman. Neither does it allude to politics or separatism. There are no objections to its publication.

May be authorised. [AGA, (03)050, c. 21/16850, ex. e. 9000/65]

In contrast with this light censorship, when El feminismo ibérico [Iberian feminism], an essay that Capmany coauthored with Carmen Alcalde, was submitted to "voluntary censorship" in July 1969, the censors unceremoniously rejected its authorisation. The Oikos-Tau publishing house had no choice but to submit a second version in September of the same year, which was also not authorised, and then a third version in January 1970, which, finally, was approved. The censorship reports for the first version were very harsh: both of the readers (identified with numbers 25 and 31) strongly called for publication to be prohibited and proposed numerous removals:

Useful and necessary as the topic is, the author has failed to show that she is well versed or that she can present her ideas soundly. She always just mirrors the works of Engels and echoes paragraph after paragraph from Margarita Nelken, etc., and she continually admires Russian essays on sexual revolution, the only pathway that the author defends as the goal of feminism, with the destruction of all religious and political taboos-except the socialist ones-that stand in the way of achieving that objective.

Pieces of paper have been used to mark texts at the end that are unintelligible (Catalan) or dangerous.

Indicated deletions: 0. 6. 7. 8. 10. 15. 29bis. 30bis. 32b. 33b. 34b. 58. 60. 64. 65. 67. 68. 69. 70. 71. 72. 77b2.73b3.74b4.73.74.76.77.78.79.80.81.82.83.84. 85., and the two marks mentioned.

Unpublishable. [number 25]

This book seeks to establish the following idea: true feminism, in the sense of a truly liberating movement for women, is not possible without establishing socialism/communism. The capitalist system (which to the author, in this context, means anything that is not radical socialism) crushes women. Constant quotations of Engels..., Nelken... Exaltation of Russia as a model.

According to the author, the Gospel is a tool to knock women down. (p. 8) Quotations are taken from the Bible in a totally arbitrary manner. Criticism of the Women's Division and Opus Dei verges on insult and defamation. (pp. 64-66)

In short, I believe this book goes beyond the boundaries of what can be authorised. Deletions cannot fix it. The overall thesis put forward is false and subversive. It aims to liberate women (as used to happen for the working class) using only one method: class hatred (now, gender hatred) and revolution. 
May not be authorised. [number 31] [AGA, (03)050, c. 66/03298, e. 7593/69]

Oikos-Tau director Jordi Garcia Bosch - somewhat irritated by the hurdles hindering the book's publicationtried again with a new, partly updated version (foreword, new titles, small edits and additions). The new version, however, did not include many of the changes that the initial censors had demanded, since it included many of the passages that they had marked in red. The report by the second reader (number 20) once again rejected the book, reaffirming some of the arguments and observations made by his colleagues:

Though essentially historical, the feminist thesis that the author seeks to put forward is that of emancipating woman so that she might not be bound by traditional standards of Christian womanhood, mainly regarding the use of sex, and that she might then become free in all other areas. Her ideal is that of the free woman proclaimed years ago by Russian Communism. She believes that she is a continuation of the work by the famous author Nelken, whom she follows in all areas and surpasses.

Based on the words of the actual text, only two one-line fragments would need to be deleted, on pages 20 and 97. But it is not about the texts, but rather the work as a whole, which, besides, offers no positive value. My opinion, therefore, is that

It may not be published.

[number 20] [AGA, (03)050, c. 66/03298, e. 7593/69]

The third version submitted was analysed by reader number 51, Alfonso Álvarez Villar, who had also analysed El feminismo ibérico. Though he still noted the book's ideological shortcomings, he adopted a more conciliatory, tolerant approach, which, of course, was necessary for the book's definitive authorisation in April 1970:

It is a very interesting book about the problems of the Spanish woman and women in general. The author uses research typical of journalism rather than of books, but generally speaking, its theses can be backed up.

Reading between the lines, there are hints of pro-communism and pro-socialism, and for that reason it is essential to remove an expression used on page 81 , in which she indirectly praises La Pasionaria. ${ }^{5}$ It is also necessary to delete a paragraph on page 20 , not only because it is an attack against the Church, but also because it is unfair.

Generally speaking, however, it is a positive book, repeating the ideas put forward by the Countess of Campo Alange, Lilí Álvarez and the suffragettes.

Conclusion: authorised, with deletions on pages 20 and 81.

[Handwritten:] I believe that, within the overall context of the book, the deletions indicated are not particularly significant. It could be authorised as is, though this would not exactly be advisable, given its socialistic theme and its rather commie-like tone. [AGA, (03)050, c. 66/03298, e. 7593/69]

In any case, the fact is that the published version still contained the allusions to the Gospel and the chapter on the "Women's Division" of Falange Española and Opus Dei (chapter 11 in the final version) that so outraged reader number 31. It included most of the content proposed for removal by the first three censors. Even the more recent content deletions proposed by Álvarez Villar, underlined below, were included, although Villar himself played down their significance:

"Christian ideologies - the robust Manichaeism of the Church Fathers-and the Gospel tangibly contribute to the oppression of women." (p. 20) (Capmany, 1970b: 20)

"Clara Zetkin [...], Rosa Luxemburg, Dolores Ibárruri and so many other women are clear testimony to the possibility of a woman becoming a leader when she is duly integrated into a new collective consciousness.” (p. 81) (Capmany, 1970b: 81)

\footnotetext{
${ }^{5}$ La Pasionaria refers to Isidora Dolores Ibárruri Gómez, a Republican heroine of the Spanish Civil War, who famously used the slogan "No pasarán” (They shall not pass) during the Battle for Madrid in 1936.
} 
Some references to Friedrich Engels were removed, albeit probably through self-censorship. These included the glosses on the idea of the "great historical defeat of the female sex" that was the main theme of the section on "The moment of the great defeat" in the chapter titled "Feminist movements," and the glosses on the shared oppression of women and the proletariat at the start of the chapter titled "Working women: the home in crisis." The fragments from the original typed version that were directly censored, rather than watered down, and did not appear in the final published edition include the following:

"When the question of women is raised, there is always somebody willing to say: 'We can't forget that half of all humans are female.' That is true. But none of us ever consider discussing 'the question of men,' even though the other half of all humans are male. So, when dealing with problems that particularly affect women, or that women raise, or that are raised regarding women, we are dealing with something that is not related only to the number, but rather to a particular situation, and that at the same time affects all of humanity. The fact is that we cannot transform society without transforming the situation of woman."

"La femme dans le monde moderne" [Women in the modern world], Recherches Internationales, Semaine de la Pensée Marxiste. Paris 1964 (initial quotation)

It is with the advent of mechanisation, in the industrial era, that woman was (sometimes unwillingly) pulled out of the home for the entire day and would live alongside male and female colleagues for the first time, thus acquiring some self-awareness as a human being who sleeps, eats and works. And it is socialism - the honest kind, of course - that pulls the woman away from her family and places her on the rugged pathway to individuality. (p. 11-this was the closing paragraph of the chapter titled "Feminist movements")

Having collapsed, in some countries more quickly than in others, there was nothing left of feminist movements by 1930, and the harsh law of capitalism will soon bring devastation to the entire world. (p. 15) (cf. Capmany, 1970b: 25)

It is difficult to determine what, in recent years, has impeded-and even reversed - the progressiveness of this sexual policy [that of the fledgling years of the USSR]. Perhaps the change of mind-set needed to implement it was not occurring at the same pace as innovations. (p. 70-71) [AGA, (03)050, c. 66/03298, e. 7593/69] (cf. Capmany, 1970b: 83)

Similarly, the essay El feminisme a Catalunya (Feminism in Catalonia), submitted for censorship in the summer of 1972, suffered numerous deletions. Specifically, the censor on duty (number 13) marked three sections with red pencil which were removed in the first edition published by Nova Terra (after the censorship process concluded on February 27, 1973). The censor described the first two deletions as referring to "the persecution of Catalan" in 1939 and "the oppression of Barcelona" in the 1920s:

"When, in 1939, the Women's Division of [the far-right] FET opened premises on [the Barcelona street] Carrer Més Baix de Sant Pere, it found a perfect institution for its goals, from which, notably, it would ban the use and promotion of the Catalan language.» (p. 70) (Capmany, 1973: 83)

"In 1917, Feminal would close, as the petite bourgeoisie did not have the money to fund a magazine for women. And when the World War ended, the industrial bourgeoisie's reaction was too destructive to leave space for a debate on the distribution of rights and duties, on the ultimate benefits of a peaceful human race, in a city that had been taken by arms.

Feminism is no longer a social reality because in Barcelona, now a garrison thanks to the power of General Martínez Anido and Captain General Milans del Bosch, you cannot afford to have any kind of seciallife." (p. 81) (Capmany, 1973: 93)

The third section removed was much more extensive, occupying four pages in the original typescript sent to the censors. Capmany included several extracts from an article published by Pilar Primo de Rivera in the Falangist publication Arriba and from an anti-feminist speech by José Antonio Primo de Rivera, both of which illustrate how the Falange's ideology relegated women to a subsidiary role. In both cases, Capmany made ironic comments implicitly criticizing the Falange's "new mystique of womanhood" as backward and that it went against the rights of women. The pages marked in red pencil by the censor and removed from the published version of the text read as follows: 
Meanwhile, the new mystique of womanhood is already under way. Its goal is to eradicate an attitude that by its very nature is considered dangerous, since it threatens the integrity of the family, society and country. This text is explicit:

"La Nueva Mujer de España" [The new Spanish woman] by Pilar Primo de Rivera. Arriba. Buenos Aires, September 10, 1938.

"Gone is the ultra-modern Institut Escola schoolgirl, a young intellectual who, with all the earnestness of a new Cato, was able to censure the 'mistakes,' 'defects' and 'vices' of a certain Felipe II, who do not know about the wonderful work of colonisation that we did in America, other than based on the eriticism of Friar Bartolomé, which they have added to. Gone is the empty woman who, knowing nothing, was unable to know herself or how to be a woman.

There is no room for her in the new Spain. New Spanish Woman! If the old saying is true that you cannot give what you do not have, it is just as true that whoever has plenty can give plenty, and we, as humble, unassuming women, must give. We must give plenty and give good things. New horizons! Women's horizons! A Mother's horizons! For us to train future conquerors of empires, to train sons of Spain who know and love their Fatherland, we must first know and love the Fatherland ourselves."

The ultra modern Institut Escola schoolgirl was a woman who intended to work and study with the same empowerment as a man, but this modern woman was in the past. The contemptuous tone with which the expression "ultra-modern" was used was reminiscent of Ortega's famous words: "not at all modern, but very twentieth century." That is, twentieth century in the sense of a new political approach that was anti-liberal and belligerent and would hold back any political proposals that might destabilise the established order. The new, not-at-all-modern Spanish woman proposed by Pilar Primo de Rivera had only to acquire the bare minimum knowledge to make herself useful without steering her away from her maternal mission:

"New Spanish Woman! When a friend facetiously criticizes what Spain did or stopped doing at some moment or another, when an enemy dishonours our Fatherland, making defamatory statements so frequently that they are accepted by one and all, then, if you know the history of the Fatherland you will stand up for her, and if you know her so well that you are proud of her, you will ensure that all and sundry finally appreciate her values. That is not all for the new Spanish woman. New Horizons. Women's horizons. The centre of a whole world, the great world of the family."

Pilar Primo de Rivera no longer talked about Feminism, which was already in the past when the Women's Division reached the height of its influence. José Antonio Primo de Rivera, meanwhile, had made very clear the new policy's attitude toward women:

"There is no other party that you will better be able to understand, since at the Falange we are not wont to use gallantry or Feminism.

Gallantry was just a way of swindlling a woman. She was buttered up with a little flattery and then sent eff into a corner, away from any serious thought. She was distracted by a concoction of words and was raised as if she were dumb, thus relegating her to a trivial, ornamental role. We understand the depths өf a woman's wonderful role, and we will make sure we never treat her like an idiot subject to flattery.

We are not feminists either. We do not believe that the way to respect a woman is to remove her from her wonderful destiny and to give her functions befitting a man. I have always found it sad to see a woman doing a man's jobs, toiling and driving herself mad in a rivalry in which she is at a huge disadvantage, much to the delight of her scornful male rivals. True feminism should not be about wanting women to take on the roles that today are considered superior, but rather about giving greater human and social dignity to women's roles."

José Antonio Primo de Rivera's ideology was inveterate male chauvinism, but his arguments and word choice accurately express the anti-feminist viewpoint situated equidistantly between the old conservative position and the new revolutionary awakening. The quoted speech is from April 25, 1935, as the conservative ideology was preparing a defence, but in the form of an attack. In Mujer y sociedad [Women and society], Lidia Falcén quotes an interview taken from an article signed by Luisa Trigo ealled "Don José Antonio Primo de Rivera no es feminista" [José Antonio Primo de Rivera is not a feminist]. The quoted section reads as follows: 
"I am not a feminist; so-suffice it to say I am not in favour of giving women the right to vote. That doesn't mean I'm an 'anti-feminist.' Those who are anti-something, whatever that something might be, portray me as nostalgic for Spanish señoritismo, which rashly but actively opposes that which is different. I am not even anti-Marxist or anti-Communist, or ... anti anything."

This new anti-nothingness - so called because its main feature is not to support any ideology was making headway along the beaten tracks of Europe. Its leader said it was a way of being, not a way of thinking. For this new doctrine, Arriba, Buenos Aires, November 26, 1938, published "Educación de las mujeres" [Education of women]:

"You must understand that we need to train the comrades in the Women's Divisions and teach them our doctrine without taking them away from the colossal mission that, as people, they have in life. Woman's true duty toward the fatherland is to form families carefully built on austerity and joyfulness, in which all traditions are shared, in which carols are sung on Christmas Day, around a Monument, in which we fully bear with the faults of others, and most importantly, in which there is abselutely no gossip, small-mindedness, half-truths, or any of these things that spoil life and make it unpleasant. This, alongside sports education and university education, will equip them to become man's true companion. What we shall never do is make them compete with men, since they will never reach their level and they are losing all the elegance and grace they need to live with men. You will soon see how these women raised in Christian Doctrine and National Syndicalism ${ }^{6}$ are useful to their family, their municipality and their union. You will soon see how in times of war, these women, just as they now do, will freely hand over their sweethearts, husbands, sons and brothers to the Fatherland."

For many years, thanks to the success of the endeavour, women right across Spain have combined their school studies with what they learnt in the home economics manual Enseñanzas del Hogar. (p. 110114) [AGA, (03)050, c. 73/02066, e. 7535/72] (Capmany, 1973: 128)

The book Cartes impertinents [Impertinent letters], meanwhile, made it through the censorship sieve without any difficulty. The initial deposit was made in the spring of 1971, and the book was approved just 14 days later, with no objections. Antonio Pardo, the only reader to issue a report, clearly read the book through a lens shaped by the Francoist viewpoint of women, but he basically considered it innocuous, since it was classified as literary:

It is supposedly a letter from the author to all kinds of women in society to make them aware of how women are made inferior to men in today's society, regardless of whether they are intellectuals or labourers, married or single, etc., etc. In other writings, the author has expressed that she is part of the struggle to promote women and to make their rights equal to those of man, reflecting Pardo Bazán and other more or less intellectual women, some Spanish, others foreign.

The letters are not significant: they are basically literature.

Publication authorised. [AGA, (03)050, c. 73/00788, e. 3868/71]

This made it easier for other essays on feminism written by Capmany in Spanish to pass through the censorship sieve, including De profesión: mujer [Profession: woman] and El comportamiento amoroso de la mujer [The amorous behaviour of women], submitted to the censors in 1970 and 1974, respectively. Nevertheless, in $D e$ profesión: mujer, the reader's report by María Reyes Llopart made some rather candid observations on how Capmany had used texts that were important to Franco's regime, including the article by Pilar Primo de Rivera, which, as seen above, had previously been censored in El feminisme a Catalunya:

The various quotations of feminist and anti-feminist authors include a reproduction of an article by Pilar Primo de Rivera (pp. 47 et seq.), but the author does not in any way criticize the article or the Falange's position on woman's role in the world. She also quotes Saint Paul, but without criticizing him. The book seeks to highlight the discrimination to which a woman is subjected, especially in the workplace and in the Civil Code, and the inadequateness of protectionist measures to improve her situation, but it does not seek to attack the current Political Regime's ideology or policy in this regard. [AGA (03)050, c. 66/06371, ex. 12780/70]

\footnotetext{
${ }^{6}$ National Syndicalism was the economic and political ideology of Fascist Spain, starting in the 1930s.
} 
The booklet La dona i la II República [Woman and the Second Republic] and the compilation of essays titled Dona $i$ societat a la Catalunya actual [Woman and society in present-day Catalonia] also made it past the censors unscathed when they were deposited in the summer of 1977 and the spring of 1978, respectively. The booklet had an introduction written by Capmany, in which, according to the reader Francisco Fernández Jardón, she showed that she was "entirely in favour of the Second Republic's political stance toward Catalan women and Catalanist women." For the compilation, reader number 17-probably Mateo Villalba-only provided a very brief summary of the content, concluding that there was no reason why the publication could be challenged and adding the short note: "No major objections to its publication."

\section{Conclusions: blatantly ideological censorship}

Although some of the decisions were rather arbitrary, Franco's censors severely mutilated Capmany's first essays because they dealt with "sensitive" topics that were an attack on the regime's ideological orthodoxy. The censors removed a long passage from La joventut és una nova classe? that contravened the Franco regime's ideals of sex and the institution of marriage, while in Pedra de toc, the more subtle excisions fiercely countered a viewpoint that was contrary to the social and political doctrine of Franco's dictatorship. In Pedra de toc 2, although the censor could not intervene, since the book was already published, he also found certain passages referring to the post-war desolation and the dichotomy between the victors and the vanquished, an uncomfortable reality for the regime.

Regarding Capmany's essays on the status of women, the censors were very unforgiving with El feminismo ibérico and El feminisme a Catalunya, forcing her to remove numerous parts, since both essays exposed the regime's religious and political taboos and attacked the entrenched model of womanhood that it upheld. $E l$ feminismo ibérico dared to offer a very frank feminist alternative, inspired by pro-socialist ideals that were poles apart from the mystique of Francoist womanhood. El feminisme a Catalunya, meanwhile, spoke out against repression during the pistolerismo ${ }^{7}$ era, the persecution of the Catalan language during Franco's dictatorship, and the anti-feminist assumptions made by Falangism. Any aspect of Capmany's essays that questioned the morality, religion or political ideology of Francoism was ultimately censored or anathematised.

Censorship proved to be much more systematic-but no less fallible or arbitrary - than Franco's other institutions of control and repression. Its main aim was to block any frontal attack against the dogmas of Francoist ideology, so it did not tolerate any kind of intellectual dissent against the regime. Censorship of Capmany's essays consisted of removing a few pages from La joventut és una nova classe? and El feminisme a Catalunya, and a few fragments from both Pedra de toc and El feminismo ibérico, including the self-censorship by Capmany herself. That was all. It is worth mentioning that the censors' intricate administrative procedures often achieved tangible results, and not just by removing content from publications and blocking tasks associated with publication. These results, however, did not match the efforts invested, as illustrated quite clearly by the case of El feminismo ibérico. The interpretations made by the readers who wrote the reports reveal which aspects gave them greatest concern, namely: the questioning of established morals and the religion on which they were founded; dissident, anti-regime political stances; and liberal interpretations of contemporary history.

Acknowledgements: This article is part of the research project "Los fundamentos del cambio cultural en España (1960-1975)" (HAR2014-52882-P), funded by the Ministry of Economy and Competitiveness.

\footnotetext{
${ }^{7}$ Meaning "gunmanism"; pistolerismo referred to the period between 1917 and 1923 during which employers would hire gunmen to kill leading trade unionists and workers.
} 


\section{References}

Capmany, M.A.: La dona a Catalunya, Barcelona: Edicions 62, 1966.

Capmany, M.A.: Dia sí, dia no, Barcelona: Llibres de Sinera, 1968.

Capmany, M.A.: La joventut és una nova classe?, Barcelona: Edicions 62, 1969.

Capmany, M.A.: Pedra de toc, Barcelona: Nova Terra, 1970a.

Capmany, M.A.: El feminismo ibérico, Vilassar de Mar: Oikos-Tau, 1970 b.

Capmany, M.A.: Cartes impertinents, Palma de Mallorca: Moll, 1971a.

Capmany, M.A.: De profesión: mujer, Barcelona: Plaza \& Janés, 1971 b.

Capmany, M.A.: El feminisme a Catalunya, Barcelona: Nova Terra, 1973.

Capmany, M.A.: Pedra de toc/2, Barcelona: Nova Terra, 1974a.

Capmany, M.A.: El comportamiento amoroso de la mujer, Barcelona: Dopesa, 1974b.

Capmany, M.A.: Cada cosa en el seu temps i lectura cada dia, Barcelona: Dopesa, 1976.

Capmany, M.A.: “Introducció.” In La dona i la II República, Barcelona: La Gaia Ciència / Edicions 62, 1977, pp. 4-6.

Capmany, M.A. et al:: Dona i societat a la Catalunya actual. Barcelona: Edicions 62, 1978. 